\title{
Determinants of Audit Committee Independence in the Financial Sector of Bangladesh
}

\author{
Bishnu Kumar Adhikary ${ }^{1}$, Ranjan Kumar Mitra ${ }^{2}$ \\ ${ }^{1}$ Graduate School of Business Administration, Kobe University, Kobe, Japan. \\ ${ }^{2}$ Faculty of Business Studies, Dhaka University, Dhaka, Bangladesh. \\ Correspondence: Bishnu Kumar Adhikary, Graduate School of Business Administration, Kobe University, Rokkodai, \\ 2-1 Nada, Kobe, Japan.
}

Received: February 29, 2016

Accepted: March 14, 2016

Available online: May 4, 2016

doi:10.11114/afa.v2i2.1591

URL: http://dx.doi.org/10.11114/afa.v2i2.1591

\begin{abstract}
This paper examines the determining factors of the audit committee independence in the financial sector of Bangladesh by employing a cross-sectional regression analysis on 72 financial firms. The paper reveals that firms with large boards and more non-executive directors tend to provide more independence to the auditors. Also, large firms with potential growth opportunities show less interest in giving freedom to the audit committee members; whereas firms with the higher leverage demand more audit committee independence to confirm quality monitoring and quality financial statements. The study, however, reveals a negative relationship between the size of the audit committee and its work independence. The study also does not find any significant association between audit committee independence and presence of experts in the audit committee, percentage of insider ownership, free cash flow, and firms' profitability.
\end{abstract}

Keywords: audit committee, audit committee independence, financial sector, Bangladesh.

\section{Introduction}

Of late, the existence of an independent audit committee as a sub-committee of the board of directors to oversee the financial reporting and auditing process has received renewed interest in controlling frauds done by accountants and managers and improving the quality of the financial reports. An audit committee can be defined as a sub-committee of the executive board that is responsible for overseeing the quality and integrity of a firm's accounting and financial reporting system, internal control system, and compliance with relevant laws, rules, and regulations. As an operating committee of the executive board, audit committee can substantially ease agency problem by reducing informational asymmetries between insiders and outsiders, and parties interested in financial decision making. Besides, audit committee provides a connection between firm's management and external auditors. Moreover, audit committee tends to provide a positive signal about the firms' earnings quality and help improve the liquidity of stocks and stakeholders' confidence in financial reporting as well. For instance, DeFond and Jiambalvo (1991), Dechow et al. (1996), McMullen (1996), and Beasley et al. (2000) argue that audit committee can lessen practices of fraudulent financial reporting and help improve earnings quality, investment decisions, and lawsuits. DeZoort(1997), Abbott et al.(2004), and Mohiuddin (2012) argue that audit committee can, at a little or no cost to the auditor, improve internal control system of a firm and increase external auditor's independence by promoting communications with the board. Such enhanced communications reduce information asymmetries between management and the board, causing the quality of monitoring and reporting improve significantly. Furthermore, the existence of an audit committee helps companies to perform better in the financial markets, which, in turn, helps them to absorb new customers (Riasi and Pourmiri, 2015; 2016) and become more competitive in their business (Amiri Aghdaie et al., 2012; Riasi, 2015a, 2015b; Riasi and Amiri Aghdaie, 2012).

Given the above, this paper studies the factors affecting the audit committee independence for firms in the financial sector of Bangladesh by using a multivariate cross-sectional regression model. The study takes Bangladesh as a case because Bangladesh shows impressive GDP growth rates (6\% plus) over the last decade despite having anomalies in the stock market. The study targets financial sector because firms operating in this industry are subject to follow stringent regulations prescribed by Bangladesh Bank (the central bank of Bangladesh) on governance and formation of audit committee. Also, Bangladesh Bank frequently monitors financial sector companies to ensure compliance with the code 
and imposes penalties to the company management for alleged cases of non-compliance. There is also a dearth of research papers that have dealt with the audit committee independence in Bangladesh thus far. For instance, Kamal and Ferdousi (2006) and Bhuiyan et al. (2007) analyzed the current regulations of audit committee in the banking system of Bangladesh. Das and Das (2007) also empirically examined disclosure of audit committee information by the listed companies of Bangladesh. In contrast, Hossain and Khan (2007) provided a comprehensive literature review of a fast growing theoretical and empirical literature on audit committee. However, till date no extensive research has been made to examine the contributing factors affecting the independence of the audit committee in the financial sector of Bangladesh. The current study fills this gap.

The study detects that firms with a large board and more non-executive directors tend to provide more freedom to the audit committee. However, the freedom of the audit committee declines with the increase in firm's size. The study further unveils that the higher levered firms demand for more audit committee independence over the low levered firms. Besides, firms having potential growth opportunities are less likely to provide freedom to the audit committee. These findings are expected to benefit the managers, shareholders and policymakers such as Bangladesh Bank and the Securities Exchange Commission (SEC) in refining the governance system of the firms in the financial sector of Bangladesh.

The rest of the study is structured as follows: Section 2 deliberates relevant theories and literature and formulates hypotheses of the study. Section 3 discusses research method. Section 4 presents empirical results. Section 5 concludes with some suggestions for future research.

\section{Theories, Empirics, and Hypotheses}

This study adopts the "agency theory" as a framework for testing the hypotheses it develops. The agency theory suggests that information asymmetry increases when there is a separation between management and the ownership of business. Multiple agency problems also exist when firms adopt more managers and become increasingly larger. In other words, agency problem ignites reduction in stockholders' wealth by creating "moral hazard" and "adverse selection". Thus, firms adopt a set of laws and regulations, and design incentive structures to incentivize managers and to strengthen the quality of reporting systems or for that matter to mitigate the agency problem. Among other things, the existence of an audit committee as a sub-committee of the executive board, giving them enough autonomy to supervise the financial reporting and auditing process, is viewed as an effective tool in reducing information asymmetry and improving firm's financial reporting quality.

In empirical works, a large body of literature also documents a positive connection between the existence of an audit committee and quality financial reporting of a firm. For example, Lin and Wang (2010), Dechow et al. (1996), and McMullen (1996) unveil that firms that have an independent audit committee are less likely to manipulate profits, more likely to disclose information voluntarily, and more likely to present quality financial reporting. Likewise, Garcia-Meca and Sanchez-Ballesta (2009) argue that independence of the audit committee can significantly improve quality and credibility of financial reporting. Cohen and Hanno (2000) further highlight that the existence of an independent audit committee significantly influences the risk assessment quality of the manager.

The existence of an independent audit committee also provides a signal of a firm's commitment to good corporate governance (Sommer 1991). DeZoort (1997) notes that an independent audit committee acting as a governing body improves corporate governance practice in the firm. Collier (1996) investigates the performance of audit committees for firms in the UK and finds that audit committees with non-executive directors disclose more information voluntarily against others. Carcello et al. (2002) study factors associated with voluntary disclosure of audit committee charters and find that firms that disclose more audit committee activities have more freedom to the audit committee. Beasley (1996) notes that incidence of financial frauds largely deters the independence of the board of directors. Bedard et al. (2004) argue that objectivity in financial reporting process can be be ensured when audit committee has more independent members. Moreover, Abbott et al. (2004) claim that there is an inverse relationship between an entirely independent audit committee and the occurrence of the earnings restatement. Furthermore, Chan and $\mathrm{Li}$ (2008) note that firm's value and goodwill can be be significantly increased when independent directors are included in the audit committee. Notably, the primary duty of an audit committee is to protect stakeholders' interest, however, the quality of the auditing functions depends on the firm's working environment (DeAngelo, 1981). Thus, it is argued that audit committee should be free from management's intervention to ensure the interest of the shareholders (Mohiuddin, 2012).

It is worth to note that the prime objective of forming an audit committee may be misleading if more insiders are included in the committee. Dechow et al. (1996) and Klein (2002) find that fraudulent financial activities of a firm are greatly reduced when independent members are appointed to the audit committee. Gendron et al. (2004) note that members who are willing to be active and productive in the audit committee should have a probing attitude that helps them assess the management's different decisions. Collier (1996) argues that that audit committee can substantially reduce the number of external audits. However, it is hard to conclude that such committee can reduce audit fees. Similarly, 
Turley and Zaman (2007), in a research of UK- based firms, conclude that audit committees to some extent influence the internal control system of a firm but they rarely discuss or challenge the audited reports. Klein (2002) and Carcello and Neal (2000) further argue that audit committees may underperform if adequate freedom is not given to them, meaning that they will seldom raise questions on the quality of financial reports. Recently, Al-Najjar (2011) finds that audit committees tend to be more independent when firms have large boards and more insider ownership. He also traces a negative connection with firm size and audit committee freedom which indicates reluctance of large firms to give freedom to the audit committee member.

Menon and Williams (1994) note that outside directors' improve the effectiveness of an audit committee. Deli and Gillan (2000) find that firms' growth opportunities and managerial ownership inhibit audit committee independence although it does not do so with firms' size and leverage. Mendez and Garcia (2007) report evidence of a negative relationship between audit committee activity and leverage. Maria (2012) argues that board's characteristics and the size of audit firms largely influence independence, activity and specialization of audit committees. She also concludes that firms with more outsiders in the board favor independent audit committees to alleviate information asymmetry between outsiders and insiders, permitting effective control of management actions.

For the effective functioning of an audit committee, the leadership (i.e. the chairmanship) is another important factor. In some firms, the Chief Executive Officer (CEO) holds the chair position of the audit committee. This hampers not only freedom of the audit committee but also impedes to perform the assigned duties efficiently. Beasley and Salterio (2001) report that audit committees with more freedom are less likely to be associated with CEO duality. They also find a positive connection between non-employee directors and audit committee independence. Chan and Li (2008) note that audit committee independence is greatly hampered when CEO becomes the chair of an audit committee. This may also result in a substantial negative value for the firm. Recently, Husam et al. (2013) and Suyano (2012) reveal that reputation of audit firms, audit fees, availability of auditors, auditors' experience, and size of audit firms promote audit quality and freedom of the audit committee.

Given the above discussion, this study classifies all the experimental variables that are likely to affect audit committee independence into four broad categories: firm-specific factors, characteristics of audit committee, board structure, and insider ownership (Fig 1). A brief discussion of all these factors and relevant hypotheses is outlined below.

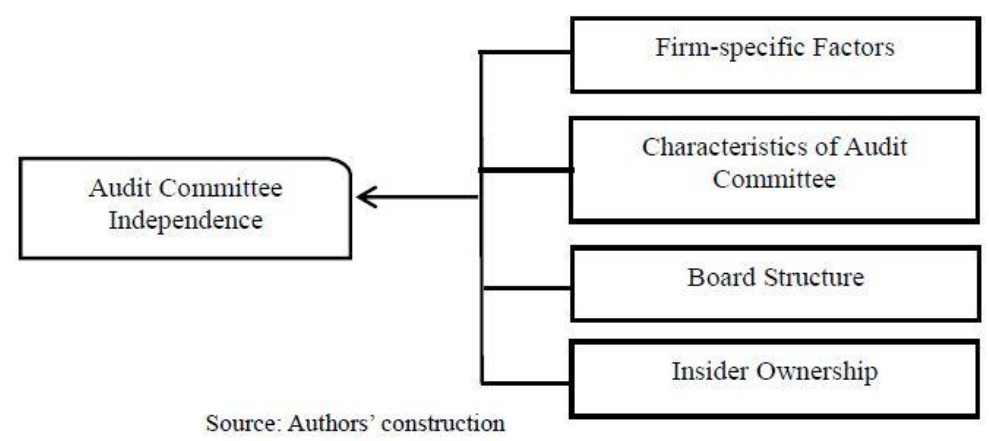

Figure 1. The four broad factors affecting audit committee independence

\subsection{Firm-specific Factors}

\subsubsection{Firm Size}

Firm size is fundamental of many theories in auditing research, including the agency cost. Large firms can afford costs of stringent monitoring mechanisms, suggesting higher audit committee freedom (Klein, 2002). Large firms may also have greater internal control system over smaller firms (O'Reilly, 1998). If a firm's internal control system performs the monitoring functions efficiently, which is often seen in large firms, then, it needs a lower level of audit committee independence (Klein, 2002). We take the above argument in account and infer that large firms require less or few alternative control mechanisms to ensure audit committee independence. This argument is consistent with Al-Najjar (2011). Our hypothesis regarding the firm size is:

\section{$H_{1}$ : Firm size negatively affects audit committee independence}

\subsubsection{Financial Leverage}

Usually, creditors demand audit committee independence when they inject more debts to the firms. This is because 
managers sometimes manipulate earnings to delay or avoid violation of debt contract. For example, Dechow et al. (1996) conclude that managers exaggerate earnings in the year before violations of debt covenants. This implies that as the firm's financial leverage increases, the creditors' demand for firms to monitoring the integrity of the financial reports increases, so does the demand for auditors' freedom. However, Al-Najjar (2011) reveals a significant negative relationship between financial leverage and audit committee independence, indicating that debt providers serve as an additional active monitoring agent in highly levered firms to control firms' opportunistic behavior and reduce the demand for audit committee independence. These confounding findings advocate us to draw the following hypothesis on financial leverage and audit committee freedom.

\section{$\mathrm{H}_{2}:$ Financial leverage and audit committee independence is positively related.}

\subsubsection{Growth Opportunities}

Firms with rapid growth may expose to mismanagement of earning and assets including the internal control system. Klein (2002) notes that growth firms can be exposed to greater uncertainties and intricacies in conducting business. So, they rely more on insider directors, not on non-executive or independent directors. He notes that managers and shareholders of high growth opportunity firms do not like to have an independent board and independent audit committee as well to control business complexities. This result supports the findings of Deli and Gillan (2000). Thus, we consider firms' growth opportunities as an important factor in determining audit committee independence. Consequently, our hypothesis regarding growth opportunities is:

\section{$H_{3}$ : Audit committee independence is negatively related to firm's growth opportunities}

\subsubsection{Free Cash Flow}

Free cash flow allows companies to pursue opportunities that enhance shareholder value. Boone et al. (2007) consider free cash flow as an index for managers' private benefit and argue that monitoring the quality of firm decreases when managers' private benefits are high. This implies that managers' with more private benefits are less likely to place a higher demand on audit committee freedom (Al-Najjar 2011). This argument supports the views of Jensen (1986) who advocates free cash flow reductions in mitigating agency conflicts. Al-Najjar (2011) also finds that free cash flow can promote agency conflicts, suggesting demand for more internal controls within the firm. Akin to the findings of Al-Najjar (2011), our hypothesis on free cash flow is:

\section{$H_{4}$ : Free cash flow positively influences the audit committee independence}

\subsubsection{Profitability}

Th importance of profitability in providing audit committee independence has not been explored in the prior literature. Previous works demonstrate a link between audit committee independence and loss propensity of business. However, we believe that management of a firm may try to overstate profits of a firm to harvest personal gains, such as performance bonus. Thus, firms should put a strict internal control mechanism including the formation of an independent audit when there is a possibility of the private gain of insiders. Therefore, our hypothesis regarding firm's profitability is:

\section{$H_{5}:$ Audit committee independence is positively related to profitability of a firm}

\subsection{The Characteristics of Audit Committee}

\subsubsection{Audit Committee Size}

As effective monitors of corporate performance, audit committee members tend to face costly consequences such as loss of reputational capital if the entity's financial statements are manipulated and subsequently revealed by any groups (Raghunandan and Rama, 2007). This argument implies that a large audit committee performs better over a small audit committee to improving the quality of financial reporting. Besides, the inclusion of more non-executive directors in the audit committee can enrich decision-making quality of firms. Thus, our hypothesis regarding audit committee size is:

\section{$H_{6}$ : Audit committee independence is positively related to audit committee size}

\subsubsection{Audit Committee Expertise}

The presence of an expert on the audit committee may ensure quality reporting of a firm. To this end, Abbott et al. (2004) document a significant negative relationship between the presence of a member of an audit committee with financial expertise and the incidence of financial statement restatements, meaning that inclusion of a financial expert in the audit committee improves quality monitoring and firm value. Logically, more experts in finance, accounting, and auditing as the members of audit committee may help improve the overall internal control mechanism of a firm and audit committee's independence as well. Thus, we include the financial expertise of audit committee members as a determinant of audit independence. Our hypothesis, in this regard, is: 


\section{$H_{7}:$ Expertise of audit committee members promotes audit committee freedom}

\subsection{Board Structure}

\subsubsection{Board Size}

A smaller board size improves monitoring by reducing free riders and makes it easier for the CEOs to control the board. However, the larger board of directors may be more valuable due to a wide range of knowledge and experience available. Additionally, Collier (1993) and Beasley and Salterio (2001) prove that firm's capability to hire more non-executive directors increases when board size increases. Arguably, organizations try to increase the number of directors on the board to choose quality audit committee members (Maria, 2012). On the same note, Klein (2002) indicates that large boards favor more non-executive directors in selecting members of audit committee to enhance quality financial reports. Consequently, our hypothesis on board size is:

\section{$H_{8}$ : Board size positive promotes audit committee independence}

\subsubsection{Board Independence}

Non-executive directors are not a part of the executive team, but their community status and experience provide great exposure for the firm (Beasley, 1996; Dechow et al., 1996). Similarly, Klein (2002) argues that the greater the number of non-executive directors on the board, the higher the chances of having more audit committee independence. Klein (2002) and Al-Najjar (2011) hypothesize a positive relationship between non-executive directors on board and audit committee independence. Besides, Raghunandan and Rama (2007) note that non-executive directors are more important over others in reflecting efficient corporate governance. Thus, our hypothesis regarding non-executive director is:

\section{$H_{9}$ : Audit committee independence is positively related to proportion of non-executive directors on the board}

\subsection{Insider Ownership}

The impact of insider ownership is not much examined in the literature of audit committee independence. Al-Najjar (2011) argues that insider ownership can reduce agency conflicts. We believe that increase in insider ownership can efficiently perform monitoring activities of a firm, and so does its reporting quality. Hence, our hypothesis regarding insider ownership is:

\section{$H_{10}$ : Insider ownership positively influences audit committee freedom}

\section{Research Methods}

This is an empirical research that aims at identifying determining factors of quality audits in the financial sector of Bangladesh. We applied both bivariate and multivariate analyzes to understanding the relationship between audit committee independence and other independent variables. We employed a cross-sectional regression method to test hypotheses of the study. Also, we checked multicollinearity problem among the variables by using variance inflation factor (VIF) to make our estimate robust.

\subsection{Sample Description and Data Collection}

We used a sample of 72 (seventy-two) listed companies from the financial sector of Bangladesh. The companies are listed on Dhaka Stock Exchange (DSE). In total, 99 (ninety-nine) firms are listed in the DSE under the financial sector. Out of these listed companies, 72 (72.73 percent) firms were selected using the simple random sampling technique. We collected annual reports of the sampled companies for the fiscal year 2012 and content analyze these reports extensively to gather information for the audit committee and other financial information. The population and sample are shown in Table 1:

Table 1. Population and sample description of this study

\begin{tabular}{cccc}
\hline Financial Sector & Population & Sample & Percentage \\
\hline Banks & 30 & 30 & $100 \%$ \\
Insurance Companies & 46 & 32 & $69.57 \%$ \\
Financial Institutions & 23 & 10 & $43.48 \%$ \\
Total & 99 & 72 & $72.73 \%$ \\
\hline
\end{tabular}

\subsection{Variable Definition}

The dependent and independent variables are summarized in Table 2, including their definition and expected nature of their relationship with audit committee independence: 
Table 2. Description of the Research variables

\begin{tabular}{|c|c|c|c|}
\hline Variables & Acronym & Definition & Expected Sign \\
\hline \multicolumn{4}{|l|}{ Dependent Variable } \\
\hline $\begin{array}{l}\text { Audit Committee } \\
\text { Independence }\end{array}$ & INDAUD & $\begin{array}{l}\text { Percentage of non-executive directors on } \\
\text { audit committee. }\end{array}$ & \\
\hline \multicolumn{4}{|l|}{ Independent Variables } \\
\hline Audit Committee Size & AUDSIZE & $\begin{array}{l}\text { Number of members of the audit } \\
\text { committee. }\end{array}$ & + \\
\hline Board Size & BOD & $\begin{array}{l}\text { Number of members of the board of } \\
\text { directors. }\end{array}$ & + \\
\hline Board Independence & INDEP & $\begin{array}{l}\text { Percentage of non-executive directors on } \\
\text { the board. }\end{array}$ & + \\
\hline Insider Ownership & INS & $\begin{array}{l}\text { Insider ownership is the number of shares } \\
\text { held by directors and other company } \\
\text { executives over the number of shares } \\
\text { outstanding }\end{array}$ & + \\
\hline Financial Leverage & LEV & Total liabilities to total assets ratio & + \\
\hline Earnings Per Share & EPS & Net profit after tax per share & + \\
\hline Market to Book Ratio & MB & $\begin{array}{l}\text { Ratio of market value of equity to book } \\
\text { value of equity }\end{array}$ & - \\
\hline Free Cash Flow & FCF & Free cash flows per share & + \\
\hline Market Capitalization & SIZE & $\begin{array}{l}\text { Natural } \log \text { of market capitalization that is } \\
\text { equal to stock price at year end times the } \\
\text { number of shares outstanding }\end{array}$ & - \\
\hline Expert & EXPERT & $\begin{array}{l}\text { Dummy variable that takes one if at least } \\
\text { one member of audit committee is expert }{ }^{1} \\
\text { and zero otherwise }\end{array}$ & + \\
\hline
\end{tabular}

\subsection{Regression Model}

We employ a cross-sectional regression model to understand the determinants of audit committee independence in Bangladesh. The regression model is as follows:

$$
\begin{gathered}
I N D A U D=\alpha+\beta_{1} A U D S I Z E+\beta_{2} B O D+\beta_{3} I N D E P+\beta_{4} I N S+\beta_{5} L E V+\beta_{6} E P S+ \\
\beta_{7} M B+\beta_{8} F C F+\beta_{9} S I Z E+\beta_{10} E X P E R T+\varepsilon---(1)
\end{gathered}
$$

Where:

$I N D A U D=$ Percentage of non-executive directors on the audit committee

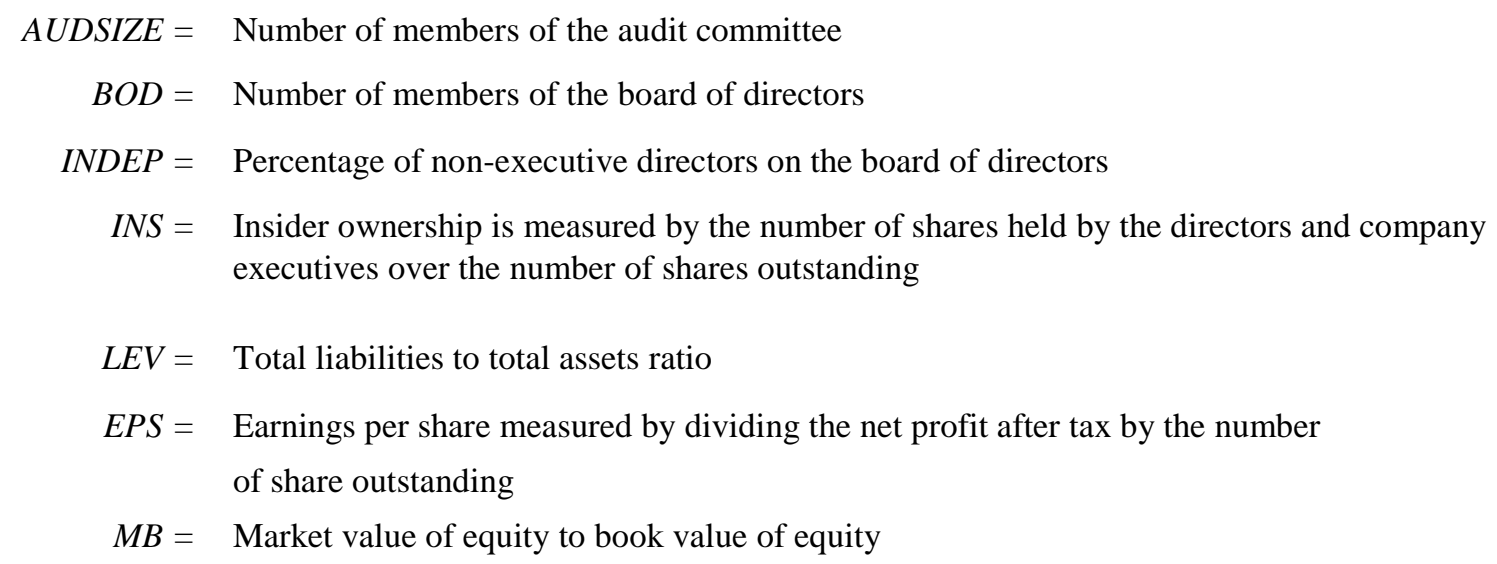

\footnotetext{
${ }^{1}$ Consider expert if one has either academic or professional knowledge in accounting, auditing or finance.
} 
$F C F=$ Free cash flow per share

SIZE $=$ Firm size is measured by natural log of market capitalization

EXPERT $=$ Dummy variable that takes 1 if at least one member of audit committee is expert and zero, otherwise

\section{Results}

\subsection{Descriptive Statistics}

Table 3 presents summary statistics of the dependent and independent variables used in the regression model of this study. This Table reveals that on average 27 percent of the members of the audit committees are made up of non-executive directors. Audit committees have an average of more than 4 (four) members while the board of directors has an average of 14 (fourteen) members. The presence of non-executive directors on boards is only 14 percent. Therefore, the percentage of non-executive director on the board is less than that of audit committee. Raghunandan and Rama (2007) suggest that the non-executive director on the board should be more than 50 percent to establish good corporate governance. From this point of view, the financial sector of Bangladesh is lagging behind the adequate number of non-executive directors essential for maintaining a proper balance on the board.

Table 3. Descriptive statistics

\begin{tabular}{|c|c|c|c|c|c|c|}
\hline Variables & $\mathrm{N}$ & Mean & Median & $\begin{array}{c}\text { Standard } \\
\text { Deviation }\end{array}$ & 1st Quartile & 3rd Quartile \\
\hline INDAUD & 72 & 0.27 & 0.25 & 0.16 & 0.20 & 0.33 \\
\hline INDEP & 72 & 0.14 & 0.11 & 0.09 & 0.09 & 0.16 \\
\hline BOD & 72 & 13.79 & 14 & 3.90 & 11 & 17 \\
\hline AUDSIZE & 72 & 4.43 & 5 & 1.24 & 3 & 5 \\
\hline LEV & 72 & 0.66 & 0.74 & 0.29 & 0.40 & 0.91 \\
\hline $\mathrm{FCF}$ & 72 & 12.11 & 5.72 & 19.63 & 2.93 & 12.61 \\
\hline INS & 72 & 0.42 & 0.41 & 0.15 & 0.35 & 0.51 \\
\hline MB & 72 & 1.89 & 1.63 & 1.74 & 1.24 & 2.18 \\
\hline SIZE & 72 & 22.20 & 22.28 & 1.25 & 21.12 & 23.28 \\
\hline EPS & 72 & 2.43 & 2.01 & 1.81 & 1.465 & 2.84 \\
\hline EXPERT & 72 & 0.51 & 1 & 0.50 & 0 & 1 \\
\hline
\end{tabular}

On the other hand, firms' dependency on debt financing on average is 66 percent, implying that most of the firms in financial sectors depend more on its debt rather than on its equity to run its operations. The financial firms produce on an average of Tk.12 as free cash flow per share which is greater than the amount of earnings per share. It implies that financial sector firms are generating, on an average, more cash over their earnings per share. Also, growth opportunities (market to book ratio) and earnings per share have means of 1.89 and Tk. 2.43, respectively. Besides, corporate insiders hold almost 42 percent of outstanding shares. This significant amount of insider ownership may positively contribute to the enhancement of the overall internal control system of the firm and ensure good corporate governance.

\subsection{Correlation Analysis}

The Pearson correlation coefficients are used for the correlation analysis between variables (Table 4). Accordingly, at a significance level of $1 \%$, the correlation coefficients for INDAUD show a significant positive relationship with INDEP $(+0.57)$ and significant negative association with AUDSIZE (-0.41). On the other hand, considering a $10 \%$ significance level, the correlation coefficient for INDAUD shows a significant negative correlation with MB (-0.20) and EXPERT $(-0.21)$. Other insignificant correlation coefficients are LEV $(+0.14)$, FCF $(+0.11)$, INS $(+0.06)$, SIZE $(+0.01)$, BOD $(-0.12)$ and EPS (-0.07). We also calculate variance inflation factor (VIF) to diagnose the existence of multicollinearity problem and find that variance inflation factors (VIF) values are less than 4 for all the independent variables, suggesting that multicollinearity not is a substantial issue in this analysis. Thus, we conclude that there is no multicollinearity 
problem in our analysis after checking the result of both correlation matrix and variance inflation factor.

Table 4. Pearson Correlation Coefficient

\begin{tabular}{|c|c|c|c|c|c|c|c|c|c|c|c|c|}
\hline & 1 & 2 & 3 & 4 & 5 & & 6 & 7 & 8 & 9 & 10 & 11 \\
\hline 1 & 1 & & & & & & & & & & & \\
\hline 2 & $0.57^{* * * *}$ & 1 & & & & & & & & & & \\
\hline 3 & -0.12 & $-.36^{* * * *}$ & 1 & & & & & & & & & \\
\hline 4 & $-.41^{* * * *}$ & -0.13 & 0.11 & 1 & & & & & & & & \\
\hline 5 & 0.14 & 0.10 & $-.33^{* * *}$ & -0.04 & 1 & & & & & & & \\
\hline 6 & 0.01 & 0.11 & -0.10 & -0.03 & $0.74^{* * * *}$ & & 1 & & & & & \\
\hline 7 & 0.11 & 0.16 & $-0.21^{*}$ & -0.16 & 0.37 *** & & $0.43^{* * * *}$ & 1 & & & & \\
\hline 8 & 0.06 & 0.14 & -0.06 & 0.01 & 0.00 & & -0.04 & 0.06 & 1 & & & \\
\hline 9 & $-0.20 *$ & -0.04 & 0.12 & -0.01 & $-.32 * * *$ & & -0.16 & -0.11 & 0.12 & 1 & & \\
\hline 10 & -0.07 & -0.11 & 0.02 & -0.09 & -0.03 & & $0.21 *$ & 0.59 *** & 0.14 & -0.05 & 1 & \\
\hline 11 & $-0.21 *$ & $-0.21 *$ & 0.00 & 0.09 & -0.07 & & -0.07 & -0.16 & 0.08 & -0.12 & 0.05 & 1 \\
\hline 1. IND & UD & 3. $\mathrm{B}$ & 4. $\mathrm{AU}$ & IZE & 5. LEV & 6.SIZE & 7. FCF & 8. INS & 9. MB & PPS & 1. EXPE & \\
\hline
\end{tabular}

$* * *, * *$ and $*$ indicate significance at the level of 1,5 and 10 percent, respectively

\subsection{Regression Analysis}

Ordinary least square (OLS) multivariate regression analysis is conducted to examine the factors influencing the independence of audit committee. The results are presented in Table 5. The results reveal a significant and negative association between firm size and freedom of audit committee. This finding supports the view that large firms rely less on alternative control mechanisms because they can ensure more efficient internal control. The significant positive coefficient of financial leverage ( $L E V)$ suggests that creditors' demand higher audit committee independence possibly because they assume that managers could manipulate firm's earnings for the violation of debt contract. This argument is consistent with our hypothesis $\mathrm{H}_{2}$. We also find that a significant negative relationship exists between the firm's growth opportunities $(M B)$ and audit committee independence. This result is supportive of the view that firms with high growth opportunities are likely to have less audit independence as they rely more on insider directors than on non-executive directors.

Concerning the effect of audit committee size on the audit committee independence, we find a significant negative relationship between them, suggesting that the audit committee independence decreases as the size of audit committee increases. This result is contrary to our expectation. Al-Najjar (2011) also finds a negative but immaterial relationship between audit size and audit committee independence in his empirical study. To find out the reason, we checked the frequency distribution of non-executive directors in the audit committee. We find that most of the firms have only one or two non-executive directors on their audit committee indicating that the audit committee independence decreases as the number of members of audit committee increases.

Furthermore, we find that coefficients of FCF, INS, EPS and EXPERT are not statistically significant at the conventional level. Thus, we fail to reject the null hypotheses for these variables with audit committee independence. In other words, firm's profitability, availability of free cash flows for distribution to shareholders, managerial ownership of stocks, and the presence of accounting and finance expert in the audit committee do not significantly influence the composition and independence of audit committee.

Table 5. Results of Multivariate Regression

\begin{tabular}{lccccc}
\hline Variable & Expected sign & \multicolumn{2}{c}{ Coefficient } & $\boldsymbol{t}$-statistic & $\boldsymbol{P}$-value \\
\hline Intercept & & $0.911^{* *}$ & $(0.354)$ & 2.574 & 0.013 \\
$I N D E P$ & + & $1.004^{* * *}$ & $(0.175)$ & 5.732 & 0.000 \\
$B O D$ & + & $0.008^{*}$ & $(0.004)$ & 1.988 & 0.051 \\
$A U D S I Z E$ & + & $-0.045^{* * *}$ & $(0.011)$ & -3.964 & 0.000 \\
$L E V$ & + & $0.156^{*}$ & $(0.087)$ & 1.794 & 0.078 \\
$F C F$ & + & 0.000 & $(0.001)$ & -0.343 & 0.733 \\
$I N S$ & + & 0.010 & $(0.094)$ & 0.111 & 0.912 \\
$M B$ & - & $-0.015^{*}$ & $(0.009)$ & -1.755 & 0.084 \\
\hline
\end{tabular}




\begin{tabular}{lccccc}
\hline SIZE & - & $-0.034^{*}$ & $(0.018)$ & -1.863 & 0.067 \\
EPS & + & 0.004 & $(0.011)$ & 0.326 & 0.745 \\
EXPERT & + & -0.025 & $(0.029)$ & -0.871 & 0.387 \\
$N=72$ & F-statistic 7.061 & Prob. $>$ F 0.000 & & R-square 0.54 & Adj. R-square 0.46 \\
\hline
\end{tabular}

$* * *, * *$ and $*$ indicate significance at the level of 1,5 and 10 percent, respectively

\section{Conclusions and Avenues for Future Research}

This paper has made an attempt to trace out the determinants of audit committee independence in the financial sector of Bangladesh. In doing so, we employed a cross-sectional data analysis technique for 72 financial firms in the year 2012. We find that audit committees are likely to be more independent when firms have large boards and more non-executive directors on the board. Also, we find that large firms with potential growth opportunity place less demand on audit committee independence. Besides, the highly levered firms need more monitoring mechanism to ensure audit committee independence. We also notice a negative association between the audit committee independence and the size of the audit committee. However, we did not find any evidence of the presence of an expert in the audit committee, the percentage of insider ownership, free cash flows, and profitability with the audit committee independence.

In this paper, we investigated a single attribute of audit committee namely the independence of the audit committee. We kept our focus mainly to the determinants of the independence of audit committee without making any attempt to examine their consequences. The independent audit committee signals a firm's commitment to good corporate governance. The freedom of audit committee is also a prerequisite for protecting shareholders' right and increasing their wealth. Therefore, future research may be directed to examine empirically other attributes of the audit committee that help augment stockholders' wealth. Another avenue for future research could be investigating the impact of audit committee independence on due diligence or increase of credibility in the financial reporting process.

\section{References}

Abbott, L. J., Parker, S., \& Peters, G. F. (2004). Audit Committee Characteristics and Restatements. Auditing: A Journal of Practice and Theory, 23(1), 69-87. http://dx.doi.org/10.2308/aud.2004.23.1.69

Al-Khaddash, H., Al-Nawas, R., \& Ramada, A. (2013). Factors Affecting the Quality of Auditing: The Case of Jordanian Commercial Banks. International Journal of Businesses and Social Science, 4(11), 206-222.

Al-Najjar, B. (2011). The Determinants of Audit Committee Independence and Activity: Evidence from the UK. International Journal of Auditing, 15(2), 191-203. http://dx.doi.org/10.1111/j.1099-1123.2011.00429.x

Amiri Aghdaie, S. F., Seidi, M., \& Riasi, A. (2012). Identifying the Barriers to Iran's Saffron Export by Using Porter's Diamond Model. International Journal of Marketing Studies, 4(5), 129-138. http://dx.doi.org/10.5539/ijms.v4n5p129

Beasley, M. S. (1996). An Empirical Analysis of the Relation between the Board of Directors Composition and Financial Statement Fraud, The Accounting Review, 71(4), 443-465.

Beasley, M. S., \& Salterio, S. E. (2001).The Relationship Between Board Characteristics and Voluntary Improvements in Audit Committee Composition and Experience. Contemporary Accounting Research, 18, 539-570. http://dx.doi.org/10.1506/RM1J-A0YM-3VMV-TAMV

Beasley, M. S., Carcello, J. V., Hermanson, D. R., \& Lapides, P. D. (2000). Fraudulent Financial Reporting: Consideration of Industry Traits and Corporate Governance Mechanisms. Accounting Horizons, 14(4), 441-54. http://dx.doi.org/10.2308/acch.2000.14.4.441

Bedard, J., \& Genron, Y. (2010). Strengthening the Financial Reporting System: Can Audit Committees Deliver? International Journal of Auditing, 14, 174-210. http://dx.doi.org/10.1111/j.1099-1123.2009.00413.x

Bedard, J., Chtourou, S. M., \& Courteau, L. (2004). The Effect of Audit Committee Expertise, Independence and Activity on Aggressive Earning Management. Auditing: A Journal of Practice and Theory, 23(2), 13-35. http://dx.doi.org/10.2308/aud.2004.23.2.13

Bhuiyan, M. H., Hossain, D. M., \& Biswas, P. K. (2007). Audit Committee in Banks: Current Regulatory Framework and Disclosure Practices in Bangladesh. The Cost and Management, 35(4), 30-44.

Blue Ribbon Committee. (1999). Report and Recommendations of the Blue Ribbon Committee on Improving the Effectiveness of Corporate Audit Committees. The Business Lawyer, 54(3), 1067-1095.

Boone, A. L., Field, L. C., Karpoff, J. M., \& Raheja, C. G. (2007). The Determinants of Corporate Board Size and Composition: An Empirical Analysis. Journal of Financial Economics, 85, 65-101. 
http://dx.doi.org/10.1016/j.jfineco.2006.05.004

Cadbury Committee. (1992). Report of the Committee on The Financial Aspects of Corporate Governance. Gee Publishing Ltd: London.

Carcello, J. V., \& Neal, T. L. (2000). Audit Committee Composition and Auditor Reporting. The Accounting Review, 75(4), 453-467. http://dx.doi.org/10.2308/accr.2000.75.4.453

Carcello, J. V., Hermanson, D. R., \& Neal, T. L. (2002). Board Characteristics and Audit Fees. Contemporary Accounting Research, 19(3), 365-299. http://dx.doi.org/10.1506/CHWK-GMQ0-MLKE-K03V

Chan, K. C., \& Li, J. (2008). Audit Committee and Firm Value: Evidence of Outside Top Executives as Expert-Independent Directors. Corporate Governance: An International Review, 16(1), 16-31. http://dx.doi.org/10.1111/j.1467-8683.2008.00662.x

Cohen, J. R., \& Hanno, D. M. (2000). Auditors' Consideration of Corporate Governance and Management Control Philosophy in Preplanning and Planning Judgments. Auditing: A Journal of Practice and Theory, 19(2), 133-146. http://dx.doi.org/10.2308/aud.2000.19.2.133

Collier, P. (1992). Audit Committees in Large UK Companies. London: ICAEW.

Collier, P. (1993). Audit Committees in Major UK Companies. Managerial Auditing Journal, 8(3), 25-31.

Collier, P. (1996). The Rise of the Audit Committee in UK Quoted Companies: A Curious Phenomenon, Accounting, Business and Financial History, 6(2), 121- 140. http://dx.doi.org/10.1080/09585209600000035

Collier, P. (1997). Corporate Governance and Audit Committees, In: Sherer, M., and Turley, S. (eds.) Current Issues in Auditing. Paul Chapman Publishing Ltd, London, 70-84.

Das, S., \& Das, S. (2007). Audit Committee Disclosure of Listed Companies in Bangladesh: An Empirical Study. The Cost and Management, 35(6), 52-64.

DeAngelo, L. E. (1981). Auditor Size and Audit Quality, Journal of Accounting and Economics, 3, 183-199. http://dx.doi.org/10.1016/0165-4101(81)90002-1

Dechow, P. M., Slaon, R. G., \& Sweeney, A. P. (1996). Causes and Consequences of Earning Manipulation: An Analysis of Firms Subject to Enforcement Actions by the SEC. Contemporary Accounting Research, 13, 1-36. http://dx.doi.org/10.1111/j.1911-3846.1996.tb00489.x

DeFond, M. L., \& Jiambalvo, J. (1991). Incidence and Circumstances of Accounting Errors. The Accounting Review, 66, 643-655.

Deli, D. N., \& Gillan, S. L. (2000). On the Demand for Independent and Active Audit Committees. Journal of Corporate Finance, 6, 427-445. http://dx.doi.org/10.1016/S0929-1199(00)00016-X

DeZoort, F. T. (1997). An Investigation of Audit Committees' Oversight Responsibilities. ABACUS, 33(2), 208-227.

Financial Reporting Council (2012). Guidance on Audit Committees, London. http://dx.doi.org/10.1111/1467-6281.00012

Garcia-Meca, E., \& Sanchez-Ballesta, J. P. (2009). Corporate Governance and Earnings Management: A Meta-Analysis. Corporate Governance: An International Review, 17(5), 594-610. http://dx.doi.org/10.1111/j.1467-8683.2009.00753.x

Gendron, Y., Bedard, J., \& Gosselin, M. (2004). Getting Inside the Blackbox: A Field Study of Practices in Effective Audit Committee. Auditing: A Journal of Practice and Theory, 23(1), 153-171. http://dx.doi.org/10.2308/aud.2004.23.1.153

Hossain, D. M., \& Khan, A. R. (2007). Audit Committee: A Summary of the Findings of Some Existing Literature. The Cost and Management, 35(5), 40-57.

Jensen, M. (1986). Agency Costs of Free Cash Flow, Corporate Finance and Takeover. American Economic Review, $76(2), 323-329$.

Kamal, M. Y., \& Ferdousi, M. M. (2006). The Presence of Audit Committee in Banking Sector to Ensure Good Corporate Governance. The Bangladesh Accountant, 104-108.

Klein, A. (2002). Economic Determinants of Audit Committee Independence. The Accounting Review, 77(2), 435-452. http://dx.doi.org/10.2308/accr.2002.77.2.435

Lee, H. Y., Mandle, V., \& Ortman, R. (2004). The Effect of Auditors' and Board of Directors' Independence on Auditor Registration. Auditing: A Journal of Practice and Theory, 23(2), 131-146. 
http://dx.doi.org/10.2308/aud.2004.23.2.131

Lin, J. W., \& Wang, M. I. (2010). Audit Quality, Corporate Governance, and Earnings Management: A Meta-Analysis, International Journal of Auditing, 14, 57-77. http://dx.doi.org/10.1111/j.1099-1123.2009.00403.x

Macdonald Commission (1988). Report of the Commission to Study the Public's Expectations of Audits. The Canadian Institute of Chartered Accountants, Canada.

Maria, I. G., Frias-Aceituno, J., \& Garcia-Rubio, R. (2012). Determining Factors of Audit Committee Attributes: Evidence from Spain. International Journal of Auditing, 16, 330-352.

McMullen, D. A. (1996). Audit Committee Performance: An Investigation of the Consequences Associated with Audit Committees. Auditing: A Journal of Practice and Theory, 15, 87-103.

Mendez, C. F., \& Garcia, R. A. (2007). The Effect of Ownership Structure and Board Composition on the Audit Committee Meeting Frequency: Spanish Evidence. Journal of Corporate Governance: An International Review, 15(5), 909-922. http://dx.doi.org/10.1111/j.1467-8683.2007.00619.x

Menon, K., \& Williams, J. (1994). The Use of Audit Committees for Monitoring. Journal of Accounting and Public Policy, 13, 121-139. http://dx.doi.org/10.1016/0278-4254(94)90016-7

Mohiuddin, M. (2012). An Empirical Investigation on audit committee practices of Bangladesh: Listed companies on DSE. PhD. Thesis, Cardiff University.

O’Reilly, V. M. (1998). Montgomery is Auditing. New York: John Wiley \& Sons.

Raghunandan, K., \& Rama, D. V. (2007). Determinants of Audit Committee Diligence. Accounting Horizons, 21(3), 265-279. http://dx.doi.org/10.2308/acch.2007.21.3.265

Riasi, A. (2015a). Barriers to international supply chain management in Iranian flower industry. Management Science Letters, 5(4), 363-368. http://dx.doi.org/10.5267/j.msl.2015.2.005

Riasi, A. (2015b). Competitive Advantages of Shadow Banking Industry: An Analysis Using Porter Diamond Model. Business Management and Strategy, 6(2), 15-27. http://dx.doi.org/10.5296/bms.v6i2.8334

Riasi, A., \& Amiri Aghdaie, S. F. (2013). Effects of a Hypothetical Iranian Accession to the World Trade Organization on Iran's Flower Industry. Consilience: The Journal of Sustainable Development, 10(1), 99-110.

Riasi, A., \& Pourmiri, S. (2015). Effects of online marketing on Iranian ecotourism industry: Economic, sociological, and cultural aspects. Management Science Letters, 5(10), 915-926. http://dx.doi.org/10.5267/j.msl.2015.8.005

Riasi, A., \& Pourmiri, S. (2016). Examples of Unsustainable Tourism in Middle East. Environmental Management and Sustainable Development, 5(1), 69-85. http://dx.doi.org/10.5296/emsd.v5i1.8705

Sommer, Jr. A. A. (1991). Auditing Audit Committees: An Educational Opportunity for Auditors. Accounting Horizon, June, 91-93.

Suyono, E. (2012). Determinant Factors Affecting the Audit Quality: An Indonesian Perspective. Global Review of accounting and Finance, 3(2), 42-57.

Turley, S., \& Zaman, M. (2007). Audit Committee Effectiveness: Informal Process and Behavioral Effects. Accounting, Auditing \& Accountability Journal, 20(5), 765-788. http://dx.doi.org/10.1108/09513570710779036

\section{(cc) EY}

This work is licensed under a Creative Commons Attribution 3.0 License. 